\title{
Adaptation of Morus alba and Morus cathayana plants in a different climate and environment conditions in Indonesia
}

\author{
NANANG SASMITA ${ }^{1, \boldsymbol{v}}$, JHON HARDY PURBA ${ }^{2}$, I GUSTI AYU DIYAH YUNITI ${ }^{3}$ \\ ${ }^{1}$ Sekolah Tinggi Pertanian Kutai Timur. Jl. Soekarno Hatta No.1, Teluk Lingga, Sangatta Utara, Kutai Timur 75683, East Kalimantan, Indonesia. \\ •email: sasmita_na@yahoo.com \\ ${ }^{2}$ Universitas Panji Sakti. Jl. Bisma No. 22, Banjar Tegal, Singaraja, Buleleng 81125, Bali. Indonesia \\ ${ }^{3}$ Universitas Mahasaraswati. Jl. Kamboja No.11A, Denpasar 80233, Bali, Indonesia
}

Manuscript received: 2 December 2018. Revision accepted: 29 January 2019.

\begin{abstract}
Sasmita N, Purba JH, Yuniti IGAD. 2019. Adaptation of Morus alba and Morus cathayana plants in a different climate and environment conditions in Indonesia. Biodiversitas 20: 544-554. Mulberry (Morus alba L. and Morus cathayana Hemsl.) cultivation business as silkworm feed in Indonesia is increasing, considering the benefits of mulberry economically, ecologically and pharmaceutically. This study aimed to determine the mulberry plants adaptation to the ability of life and growth of mulberry cuttings. The research was conducted at three different places i.e. BPTH Bali, Cianjur Alam Sutra Nursery (West Java) and East Kutai Farming Farm, using Randomized Block Design consisted of mulberry treatments (M. alba and M. cathayana) and three treatments i.e. using Rootone F, Using Organic solution and Control (no added. The results show different growth rates from various regions in Indonesia. Mulberry growth in West Java was the best compared to mulberry which growth in Bali and Kalimantan. The highest live percentage was observed in West Java for M. alba (95\%) and M. cathayana (90\%), followed by Bali M. alba (85\%) and M. cathayana (80\%), Kalimantan M. alba (80\%) and M. cathayana (75\%). The best high parameter of mulberry plant in West Java for $M$. alba $(80 \mathrm{~cm})$ and $M$. cathayana $(76 \mathrm{~cm})$, in Bali for M. alba $(67 \mathrm{~cm})$ and $M$. cathayana $(76 \mathrm{~cm})$, in Kalimantan for $M$. alba $(58 \mathrm{~cm})$ and $M$. cathayana $(50 \mathrm{~cm})$. The best mulberry species based on the whole parameter is M. alba in West Java. This means that West Java climate and environmental conditions are good for mulberry cultivation.
\end{abstract}

Keyword: Adaptation, cuttings, Morus alba, M. cathayana, mulberry

\section{INTRODUCTION}

Mulberry is a fast-growing shrub or a medium-sized tree species. Mulberry is also woody and broad-leaved plant. This plant has been cultivated for silkworm's maintenance in a long time. In recent years, mulberry crops have been identified as contributing to the prevention and the control of critical land, soil and water conservation. Mulberry plants have many benefits such as leaves can be used as animals feed, fruit for consumption and mulberry tea leaf which has been explored in the pharmacy. Jian et al. (2013) states that mulberry is a species with wide geological distribution, has an abundant ecological type based on a long-term natural selection. In China, the mulberry plant is evenly distributed, cultivated from the plateau $3600 \mathrm{~m}$ above sea level from Xinjiang to the east coast of China, from the south of Hainan to the north of Heilongjiang. Mulberry in America, according to Nowak (2002), is categorized as one of the urban vegetation that directly help to improve air quality and cool down the local temperature.

Morus alba grows in a tropical and subtropical climate. These plants are shade resistant tree species. It usually grows in dwindling areas, valley areas and coastal areas. It can adapt and grow at an altitude of 0-3300 masl. The average annual temperature ranges from $0-40^{\circ} \mathrm{C}$ with an annual rainfall average $1500-2500 \mathrm{~mm}$. This plant grows in a variety of soils ranging from sandy clay to clay, but it prefers alluvial soil clay with adequate moisture and $\mathrm{pH}$ 6.0-7.5. In India, the mulberry is up to 20 years old. $M$. alba growth shows an average diameter increase of $1.5 \mathrm{~cm}$ each year and an average height increase of $1 \mathrm{~m}$ per year. Mulberry experienced very rapid initial growth, it's about $4.5 \mathrm{~m}$ in the first 2 years. Mulberry is a native plant in Cambodia, China, India, Indonesia, Japan, Laos, Myanmar, Pakistan, Thailand, Vietnam and Zanzibar. While in Ethiopia, France, Italy, Kenya, Korea Republic, Malaysia, Mozambique, Namibia, Nepal, South Africa, Tanzania, Uganda, and England are exotic species (Orwa et al. 2009). $M$. cathayana is a broadleaf plant growing up to 15 meters tall. Its habitat is in forests, on the banks of rivers, slopes or valleys, at 900 meters to 1300 meters above sea level altitude. This mulberry plant blooms from May to June, and the seeds fall from August to September. M. cathayana is a monoecious species. This plant is suitable for growing in mild (sandy), medium (loamy) and heavy (clay) soils and prefer well-drained soils. The appropriate $\mathrm{pH}$ is in acidic, neutral and alkaline soils. It can grow in semi-shade (light forest) or without shade, but prefers moist soil. This mulberry has fragile roots that need to be moved carefully when planting it. This plant is very resistant to fungi (Kong and Yang 2017).

An attempt to increase the mulberry cuttings growing percentage was done by using Rootone F. Rootone $\mathrm{F}$ is a synthesis growth regulator. Rootone $\mathrm{f}$ is a powder, with a white color, containing $0.067 \%$ naphthyl acetamide , 2 
methyl 1 naphthyl acetamide 0.013\%, 2 methyl 1 naphthyl acetamide $0.03 \%$, indole 3 butyrate (IBA) $0.057 \%$ and $4 \%$ oysters. Several studies have suggested that Rootone F use is capable of initiating root in woody plants at $5 \mathrm{ppm}$ to 200 ppm concentrations by soaking between 5 minutes and maximum 20 hours in plants that are difficult to initiate their roots (Mudiana et al. 2001; Utami et al. 2001). In addition to growing media and growth regulator, environmental factors need to be considered, for example, temperature, humidity and light intensity. These environmental factors affect the growth rate and rate of plant development (Hidayati and Saefudin 2002).

The main mind problem of natural silk in Indonesia is mulberry productivity is still relatively low, it's about 8 tons/ha/year compared to mulberry productivity in China that reached 22 tons /ha/year (Santoso 1999). The attempt to increase production of mulberry leaves were done in various ways including breeding, cultivation such as seed propagation (cuttings) and the application of biotechnology. This problem can be solved by introducing a superior mulberry species to the sub-tropical states that has a great production of natural silk. To improve mulberry productivity, it also needs a proper cultivation technique, a fast and economical mulberry breeding technique which fit with the climatic conditions of Indonesia. Another problem is the cuttings use efficient short size cuttings without reducing the ability to live and growth which means saving the use of the cuttings. For areas that are difficult to obtain cuttings, especially the superior type and very limited seed stock needs to use cuttings efficiently. Because of these problems, it is important to study the most optimal mulberry adaptation to increase the growth of various types of mulberry to achieve efficient use of cutting material. This study aimed to determine the rate of adaptation and growth of mulberry in three different regions and environmental conditions in Indonesia.

\section{MATERIALS AND METHODS}

\section{Study area}

The research was conducted in three different provinces in Indonesia, i.e., West Java, Bali, and East Kalimantan. The first location was in Indonesian Natural Silk Centre (Balai Pesutraan Alam) at Pasir Sarongge Village, Cianjur, West Java $\left(6^{\circ} 45^{\prime} 57.3^{\prime \prime} \mathrm{S}, 107^{\circ} 02^{\prime} 33.6^{\prime \prime E}\right)$. This location is a center of natural silk development in Indonesia. The location is at an altitude of 1200 meters above sea level, temperature of $15-20^{\circ} \mathrm{C}$ and an average annual rainfall of 3000-3600 mm. The research was conducted in AugustOctober 2015. The second location was in the Forestry Plant Breeding Centre (BPTH) Bali Nusa Tenggara in Denpasar, Bali $\left(8^{\circ} 43^{\prime} 22.4^{\prime \prime} \mathrm{S}, 115^{\circ} 11^{\prime} 20.0^{\prime \prime E}\right)$, with an altitude of $100 \mathrm{~m}$ asl., temperature of $26-32^{\circ} \mathrm{C}$ and an average annual rainfall of $1900-2600 \mathrm{~mm}$. The study was conducted in November 2015 to January 2016. The third location was in Agricultural Nursery of East Kutai District (Kebun Pembibitan Tanaman Kabupaten Kutai Timur), Sangatta, East Kutai. The study was undertaken at this site for testing mulberry plant species in post-mining areas $\left(0^{\circ} 31^{\prime} 60.0^{\prime \prime} \mathrm{N}, 117^{\circ} 33^{\prime} 47.0^{\prime \prime} \mathrm{E}\right)$, because East Kalimantan has a lot of open lands, which is critical and needs to be rehabilitated. The location is at an altitude of $300 \mathrm{~m}$ asl., with temperature of $27-35^{\circ} \mathrm{C}$ and an average annual rainfall of 1700-2000 mm. The study was conducted from August to October 2016.

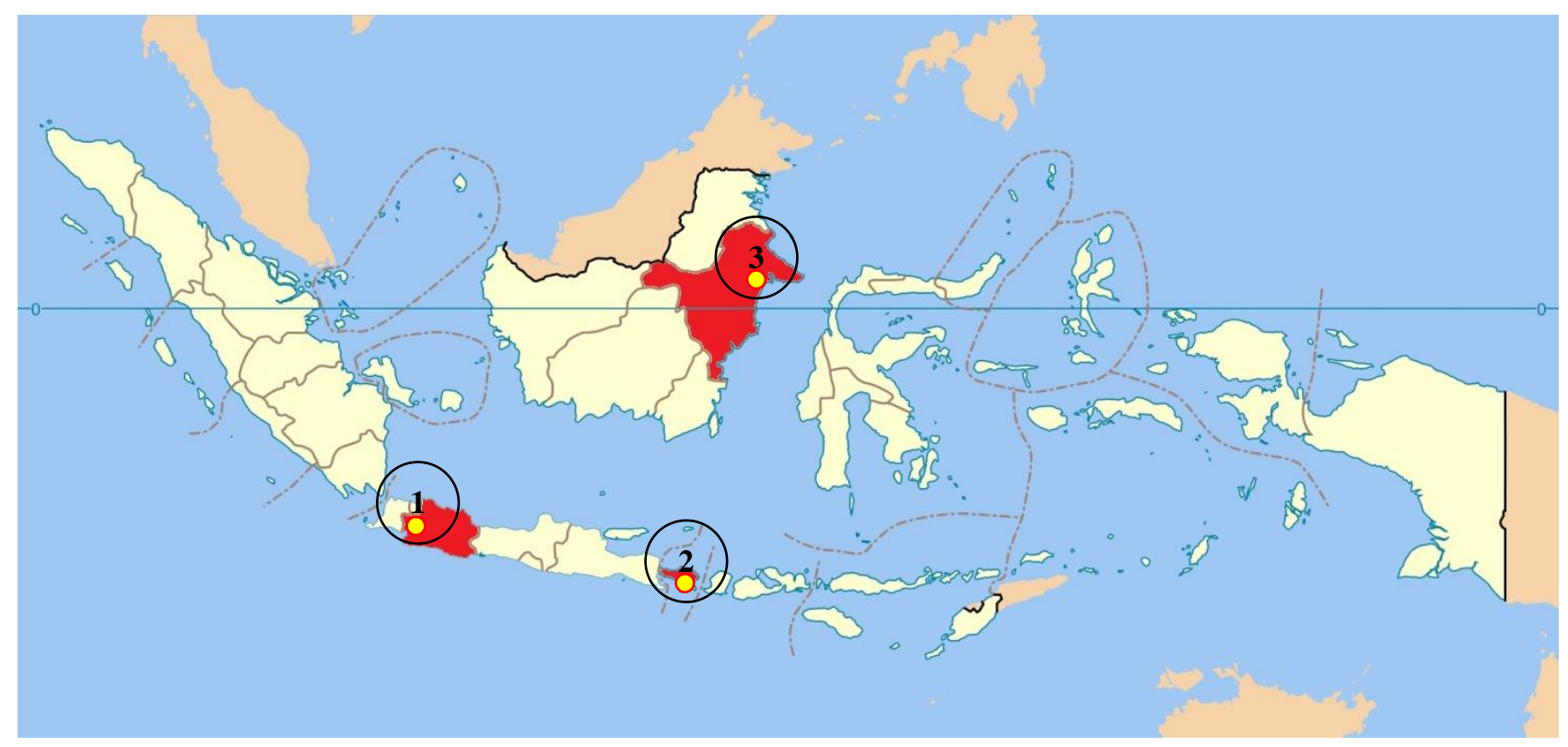

Figure 1. The study sites. 1. Natural Silk Centre (Balai Pesutraan Alam) at Pasir Sarongge Village, Cianjur, West Java; 2. Forestry Plant Breeding Centre (BPTH) Bali Nusa Tenggara in Denpasar, Bali; Agricultural Nursery of East Kutai District (Kebun Pembibitan Tanaman Kabupaten Kutai Timur), Sangatta, East Kutai 


\section{Procedures}

The procedure of research contains a few stages, such as: cuttings preparation, treatment, cuttings planting, plant maintenance (seed), and parameter measurement.

\section{Cutting}

Mulberry cuttings were taken from two years old plants, in Sarongge Village, Cianjur Regency. The plant had a good condition, free of pests and diseases. The $30 \mathrm{~cm}$ length cuttings were cut, using a sharp knife to produce a smooth cut. A smooth cut can make callus forms easily. The Callus that formed on mulberry cuttings is useful to cover the wound (Wudianto 1999). The bottoms of the cuttings were cut oblique $45^{\circ}$ while the top was flat with a $0.5-2.0 \mathrm{~cm}$ diameter. Number of mulberry cuttings which been taken are 180 cuttings $M$. alba and 180 cuttings $M$. cathayana. Total mulberry cuttings were 360 cuttings for each research location.

\section{Provision of treatment}

The cuttings were soaked in the Rootone F hormone with a $15 \mathrm{ppm}$ concentration, organic growth regulator for 5 minutes and control (without Rootone F). Organic growth regulator was made from the composition of crisp bamboo shoots, bean sprouts, banana stalks and shredded shoots that have been blended smoothly, and then mixed with boiled brown sugar water. The liquid was inserted into a plastic tub and added with bacteria decomposers and coconut water. The storage basin was covered with transparent plastic for five days and stirred daily. After five days deposited, the solution was filtered and the organic growth regulator can be used directly. The two types of mulberry cuttings with hormone treatment, organic and hormonal growth regulator were replicated three times, with 18 combinations. The growth observation was conducted for three months with parameters of life percentage, height of cuttings, stem diameter, number of leaves and number of shoots (branch). The growth data of each parameter was averaged. Standard error, which is the standard deviation of each value, was used to measure the variation of the mean values from one sample to another taken from the same distribution (Steel and Torrie 1980). Combination of randomized group treatment can be seen in Table 1.

Table 1. Treatment combination from two species mulberry

\begin{tabular}{llccc}
\hline $\begin{array}{l}\text { Mulberry } \\
\text { species } \\
\text { (M) }\end{array}$ & Growth & \multicolumn{3}{c}{ Repetition (group) } \\
\hline \multirow{3}{*}{ Regulator } & H0 (control) & M1H0 & M1H1 & M1H2 \\
& H1 (Rootone F) & M1H1 & M1H2 & M1H0 \\
& H2 (organic) & M1H2 & M1H0 & M1H1 \\
& & & & \\
& H0 (control) & M2H0 & M2H1 & M2H2 \\
M2 & H1 (Rootone F) & M2H1 & M2H2 & M2H0 \\
& H2 (organic) & M2H2 & M2H0 & M2H1 \\
\hline
\end{tabular}

Note: $\mathrm{M} 1=$ = alba, $\mathrm{M} 2=$ = cathayana, $\mathrm{H} 0=$ control, $\mathrm{H} 1=$ Rootone $\mathrm{F} 15 \mathrm{ppm}, \mathrm{H} 2$ = organic growth regulator

\section{Cuttings planting}

After the cuttings treated with the hormone Rootone F and organic growth regulator, the cuttings were planted in polybags. The polybag size was $15 \mathrm{~cm} \times 25 \mathrm{~cm}$. The media for polybag content was topsoil (fertile soil) and manure (cow dung) with a $2: 1$ cooperation. It was $2 \mathrm{~kg}$ of soil and 1 $\mathrm{kg}$ of manure.

\section{Maintenance}

Mulberry seedlings were maintained regularly for three months. The plant maintenance included cleaning the grass or dirt in polybag media. Watering the seeds was done twice a day, the morning and evening.

\section{Parameters measurement}

The mulberry seeds growth was measured to determine the effect of the treatment on both species. The measurement was done every week for three months including the height, diameter, the number of branches, the number of leaves, and the growth percent. Here are the technical guidelines for mulberry seeds measurement: (i) Growth percentage (\%), it is calculated based on the number of live plant seedlings. (ii) The height (length) of shoot $(\mathrm{cm})$, its measured from the base of buds to shoots. (iii) Stem diameter $(\mathrm{cm})$, it is measured $2 \mathrm{~cm}$ from the base of the stem. (iv) The number of shoots, it is calculated based on the number of shoots that grow at each cutting. (v) The number of leaves, it is calculated on the leaves that have grown.

Plant samples measurements were conducted based on subsample. The number of subsample of each treatment is $20 \%$ of all samples, i.e $20 \%$ × 20 cuttings planted, as many as 4 cuttings per treatment (Gomez and Gomez 1995). The total number of subsamples measured by 18 combinations multiplied by 4 mulberry cuttings, was 72 mulberry cuttings. The research instrument that was used consists of various measurement tools and documentation equipment, such as a lux meter which used to measure the intensity of sunlight, a meter tape to measure shoot length or plant height, a calipers to measure the plant stems diameter, a Thermo hygrometer to measure room temperature and humidity, a camera for the visualization and a computer for data and other related information processing.

\section{Data analysis}

The data were analyzed on the effect of plant species on the growth and mulberry adaptation at three different locations, using analysis of variance (ANOVA), followed by Duncan Multiple Range Test (DMRT) at 5\% level. Determination of the best treatment of all observed parameters was carried out with by making a ranking. Ranking was made from the highest to the lowest number. Life ability percentage parameter is an indicator to determine the success of mulberry seedlings, so that the value weight of the life ability percentage is higher. 


\section{RESULTS AND DISCUSSIONS}

\section{Growth percentage (\%)}

The growth observation results showed that there was a significant difference between the growing percentage of mulberry cuttings using Rootone-F and organic growth regulator. That difference was demonstrated by the treatment of rootone with a $15 \mathrm{ppm}$ concentration which has a relatively high cuttings percentage, whereas organic growth regulator and control produced a lower growth percentage of $60-75 \%$ (Table 2). This result is similar with the research of Nurlaeni and Surya (2015) who reported that the use of growth regulator at the right dosage may increase the cuttings growing percentage, whereas at inappropriate doses may result in stunted or abnormal growth.

The growing percentage of Rootone F treatment could increase mulberry plants in West Java for M. alba (95\%) and $M$. cathayana (90\%) compared with the organic matter treatment for $M$. alba $(75 \%)$ and $M$. cathayana $(75 \%)$ as well as control for M. alba (70\%) and M. cathayana (65\%). The growth percentage in Kalimantan was lower than in West Java for the M. alba $(80 \%)$ and M. cathayana $(75 \%)$. While the treatment of organic substances for $M$. alba $(75 \%)$ and $M$. cathayana $(75 \%)$ and control for $M$. alba $(60 \%)$ and $M$. cathayana (55\%). Compared to East Kalimantan, the growth percentage in Bali was higher, i.e. for $M$. alba (85\%) and M. cathayana (80\%) compared with organic matter treatment for $M$. alba $(75 \%)$ and $M$. cathayana $(75 \%)$ and control for $M$. alba $(65 \%)$ and $M$. cathayana $(65 \%)$.

Based on the comparison results (Figure 4) it can be seen that Rootone F contains auxin hormone with a higher auxin composition thus stimulating the formation of buds and roots. Gunawan (1995) reported that if the auxin concentration is greater than cytokinin, it makes the buds will be easily formed, if the cytokinin concentration is greater than the auxin concentration then the buds will grow faster. Table 2 shows that the growing percentage of Rootone $\mathrm{F}$ treatment is higher. Rootone $\mathrm{F}$ is a synthetic substance containing auxin hormones to stimulate root growth (Gustini 2013). The use of organic growth regulator in general increases the percentage of cuttings growing and the formation of roots and calluses. Rootone F with $15 \mathrm{ppm}$ concentration can generally result in a growing percentage and the formation of roots on mulberry cuttings is better than with other treatments. This indicates that the combination of Rootone $\mathrm{F}$ ingredients has a significant effect on the growth of cuttings and roots. Leopold (1963) and Pasetriyani (2014) reported that the growth of cuttings was influenced by several other factors such as growing media, type of cuttings, cuttings position in the plants and others.

Table 2. The average of 3 months olds mulberry plant live percentage (\%)

\begin{tabular}{|c|c|c|c|c|c|c|c|c|c|c|}
\hline \multirow{2}{*}{ Species } & \multirow{2}{*}{ Time } & \multicolumn{3}{|c|}{ West Java } & \multicolumn{3}{|c|}{ East Kalimantan } & \multicolumn{3}{|c|}{ Bali } \\
\hline & & $\mathbf{R}$ & $\mathbf{O}$ & $\mathbf{C}$ & $\mathbf{R}$ & $\mathbf{O}$ & $\mathbf{C}$ & $\mathbf{R}$ & $\mathbf{O}$ & $\mathbf{C}$ \\
\hline M. alba & 7 DAP & $20 \mathrm{~b}$ & $10 \mathrm{ab}$ & 0 & $15 \mathrm{ab}$ & $10 \mathrm{ab}$ & 0 & $20 \mathrm{~b}$ & $15 \mathrm{ab}$ & 0 \\
\hline M. alba & 30 DAP & $70 \mathrm{~d}$ & $60 \mathrm{~cd}$ & $30 \mathrm{ab}$ & $50 \mathrm{bcd}$ & $40 \mathrm{bc}$ & $15 \mathrm{a}$ & $65 \mathrm{~d}$ & $50 \mathrm{bcd}$ & 15 a \\
\hline M. alba & 60 DAP & $85 \mathrm{~d}$ & $70 \mathrm{bcd}$ & $50 \mathrm{a}$ & $75 \mathrm{~cd}$ & $55 \mathrm{ab}$ & $45 \mathrm{a}$ & $80 \mathrm{~d}$ & 70 bcd & $60 \mathrm{abc}$ \\
\hline M. alba & 90 DAP & $95 \mathrm{~d}$ & $75 a b c$ & $70 a b$ & $80 \mathrm{abc}$ & $75 \mathrm{abc}$ & $60 \mathrm{a}$ & $85 \mathrm{bc}$ & $75 \mathrm{abc}$ & $65 a b$ \\
\hline M. cathayana & 7 DAP & $15 \mathrm{~b}$ & $10 \mathrm{ab}$ & 0 & $5 \mathrm{ab}$ & $10 \mathrm{ab}$ & 0 & $10 \mathrm{a}$ & $5 \mathrm{ab}$ & 0 \\
\hline M. cathayana & 60 DAP & $85 \mathrm{c}$ & $70 a b c$ & $55 \mathrm{ab}$ & $65 a b c$ & $55 \mathrm{ab}$ & $45 \mathrm{a}$ & $75 \mathrm{bc}$ & $55 \mathrm{ab}$ & $50 \mathrm{ab}$ \\
\hline M. cathayana & 90 DAP & $90 \mathrm{c}$ & $75 \mathrm{bc}$ & $65 \mathrm{ab}$ & $75 \mathrm{~b}$ & $75 \mathrm{~b}$ & $55 \mathrm{a}$ & $80 \mathrm{bc}$ & $75 \mathrm{~b}$ & $65 \mathrm{ab}$ \\
\hline
\end{tabular}

Note: The numbers followed by the same letter are not significantly different in the 5\% Duncan Multiple Test. DAP: Day after planted; R: using Rootone F; O: using Organic and C: a control (using no added material)
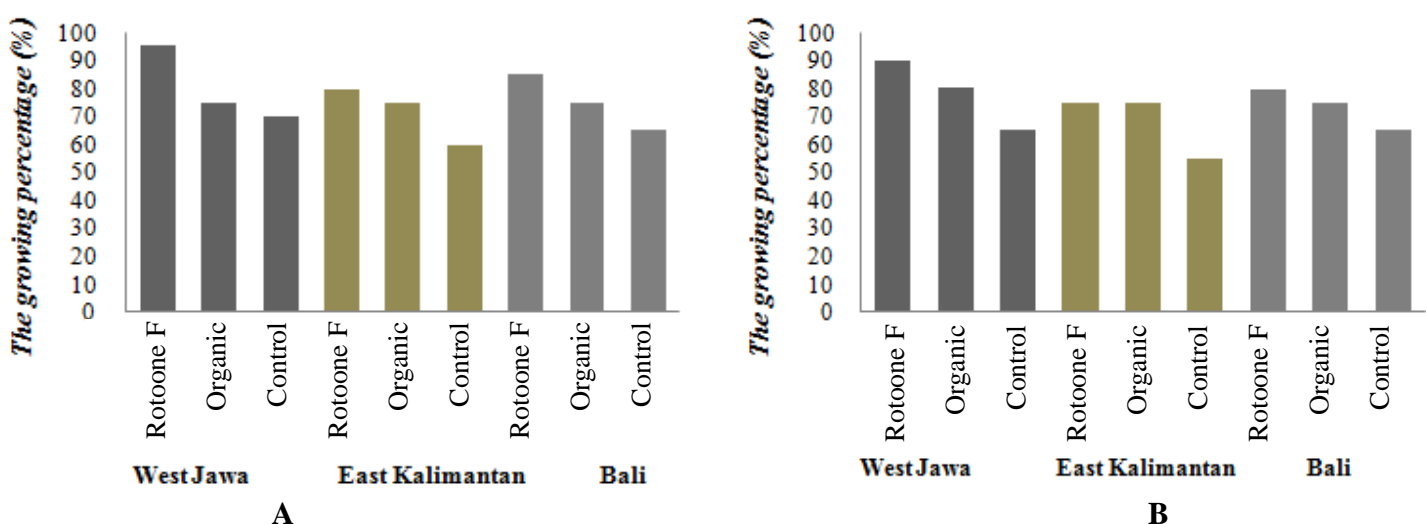

Figure 4. A. Grow Percentage of Morus alba (90 DAP), B. Grow Percentage of Morus cathayana (90 DAP) 


\section{Cutting height $(\mathrm{cm})$}

Height growth of mulberry cuttings which was given Rootone $\mathrm{F}$ and organic substances has a noticeable difference. This difference was on treatment of Rootone $\mathrm{F}$ with a 15 ppm concentration which results in a good cuttings height whereas organic and control substances resulted in low height cuttings between $35-65 \mathrm{~cm}$ (Table 3 ). On the height of cuttings, in general the Rootone $\mathrm{F}$ treatment can increase the plant height in West Java for $M$. alba $(80 \mathrm{~cm})$ and $M$. cathayana $(76 \mathrm{~cm})$ compared to the organic matter treatment for $M$. alba $(65 \mathrm{~cm})$ and $M$. cathayana $(62 \mathrm{~cm})$ and control for $M$. alba $(36 \mathrm{~cm})$ and $M$. cathayana $(34 \mathrm{~cm})$. The height growth of mulberry in Kalimantan is lower than West Java, i.e for Rootone F treatment $M$. alba $(58 \mathrm{~cm})$ and $M$. cathayana $(50 \mathrm{~cm})$, for the organic matte treatment $M$. alba $(38 \mathrm{~cm})$ and $M$. cathayana $(41 \mathrm{~cm})$ and control for $M$. alba $(32 \mathrm{~cm})$ and $M$. cathayana $(33 \mathrm{~cm})$. The height growth of mulberry in Bali is higher compared to East Kalimantan, i.e., for M. alba (67 $\mathrm{cm})$ and $M$. cathayana $(56 \mathrm{~cm})$ compared with the organic matter treatment for $M$. alba $(40 \mathrm{~cm})$ and $M$. cathayana $(38$ $\mathrm{cm})$ and control for $M$. alba $(32 \mathrm{~cm})$ and M. cathayana $(35$ $\mathrm{cm})$.

High growth (Figure 5) shows that in general, the cuttings continue to increase. The highest average cutting rate at 90 days after planting is Rootone $\mathrm{F}$ treatment followed by organic matter and control. From the Figure 5, it is seen that Rootone $\mathrm{F}$ influences the growth of cuttings of $M$. alba and M. cathayana. Along with Pulok et al. (2014) who reported that treatment of growth regulators affected the growth of plant seedlings.

The effect of growth regulators concentration makes each type of plant grows differently, even among different varieties within a species (Leopold 1963; Siregar and Djam'an 2017). The effectiveness of plant growth regulators in plants is influenced by the given concentration the difference in concentration will cause different activities. The difference in the activity of growth regulating substances is determined by the cuttings of the species used (Rochiman and Harjadi 1973; Siregar and Djam'an 2017). In addition, Djamhari (2010) reported that the application of exogenous growth regulating substances in plants can serve to spur the formation of phytohormone, thus promoting a biochemical activity. Phytohormones as organic compounds that act actively in small amounts are usually transformed to all parts of the plant so it can affect the growth or physiological processes of the plant. Based on the results of this test, it is seen that giving of Rootone F and organic matter has an effect on to growth of cuttings of M. alba and M. cathayana.

Table 3. Average of 3 months old mulberry crops cuttings $(\mathrm{cm})$

\begin{tabular}{|c|c|c|c|c|c|c|c|c|c|c|}
\hline \multirow[b]{2}{*}{ Species } & \multirow{2}{*}{ Time } & \multicolumn{3}{|c|}{ West Java } & \multicolumn{3}{|c|}{ East Kalimantan } & \multicolumn{3}{|c|}{ Bali } \\
\hline & & $\mathbf{R}$ & $\mathbf{O}$ & C & $\mathbf{R}$ & $\mathbf{O}$ & C & $\mathbf{R}$ & $\mathbf{O}$ & $\mathbf{C}$ \\
\hline M. alba & 7 DAP & $6 \mathrm{c}$ & $5 \mathrm{c}$ & 0 & $1 \mathrm{a}$ & $1 \mathrm{a}$ & 0 & $3 \mathrm{~b}$ & $3 \mathrm{~b}$ & 0 \\
\hline M. alba & 30 DAP & $25 \mathrm{f}$ & $20 \mathrm{c}$ & $9 \mathrm{bc}$ & $12 \mathrm{~cd}$ & $6 a b$ & $4 \mathrm{a}$ & $16 \mathrm{~d}$ & $14 \mathrm{~d}$ & $2 \mathrm{a}$ \\
\hline M. alba & 60 DAP & $60 \mathrm{e}$ & $34 \mathrm{~cd}$ & $18 \mathrm{ab}$ & $33 \mathrm{~cd}$ & $25 \mathrm{bc}$ & $16 \mathrm{ab}$ & $41 \mathrm{~d}$ & $30 \mathrm{c}$ & $10 \mathrm{a}$ \\
\hline M. alba & 90 DAP & $80 \mathrm{~d}$ & $65 \mathrm{bc}$ & $36 \mathrm{a}$ & $58 b$ & $38 \mathrm{a}$ & $32 \mathrm{a}$ & $67 \mathrm{c}$ & $40 \mathrm{a}$ & $32 \mathrm{a}$ \\
\hline M. cathayana & 7DAP & $5 \mathrm{a}$ & $4 \mathrm{c}$ & 0 & $1 \mathrm{ab}$ & $1 \mathrm{ab}$ & 0 & $2 \mathrm{~b}$ & $3 \mathrm{~b}$ & 0 \\
\hline M. cathayana & 30 DAP & $28 \mathrm{f}$ & $23 \mathrm{e}$ & $9 \mathrm{bc}$ & $12 \mathrm{~cd}$ & $6 a b$ & $3 \mathrm{a}$ & $15 \mathrm{~d}$ & $12 \mathrm{~cd}$ & 3 a \\
\hline M. cathayana & 60 DAP & $52 \mathrm{e}$ & $26 \mathrm{c}$ & $17 \mathrm{ab}$ & $25 \mathrm{c}$ & $21 \mathrm{ab}$ & $14 \mathrm{a}$ & $32 \mathrm{~d}$ & $22 \mathrm{bc}$ & $13 \mathrm{a}$ \\
\hline M. cathayana & 90 DAP & $76 \mathrm{f}$ & $62 \mathrm{e}$ & $34 \mathrm{a}$ & $50 \mathrm{c}$ & $41 \mathrm{~b}$ & $33 \mathrm{a}$ & $56 \mathrm{~d}$ & $38 \mathrm{ab}$ & $35 \mathrm{ab}$ \\
\hline
\end{tabular}

Note: The numbers followed by the same letter are not significantly different in the 5\% Duncan Multiple Test. DAP: Day after planted; R: using Rootne F; O: using Organic and C: a control (using no added material)

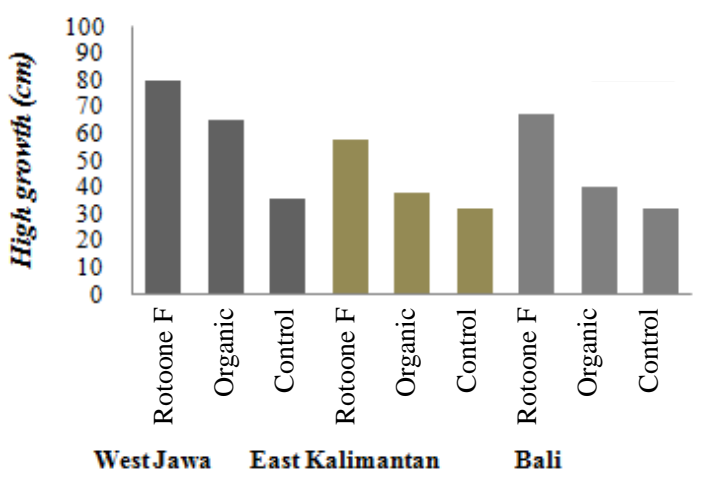

A

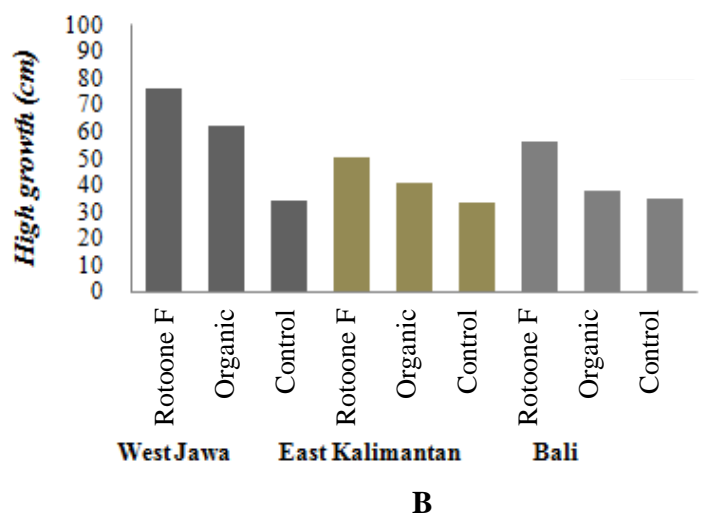

B

Figure 5.A. High of Morus alba cuttings (90 DAP), B. High of Morus cathayana cuttings (90 DAP) 


\section{Mulberry plants number of leaves (strands)}

In general, Rootone $\mathrm{F}$ treatment can increase the number of leaves in mulberry plants in West Java for $M$. alba (20 strands) and $M$. cathayana (18 strands) compared to the organic matter treatment for $M$. alba (17 strands) and $M$. cathayana (16 strands) as well as control of the type $M$. alba (12 strands) and $M$. cathayana (11 strands). The number of mulberry leaves in Kalimantan is lower than in West Java for M. alba (15 strands) and M. cathayana (13 strands). While the number of leaves for a mulberry with organic growth regulators treatment for $M$. alba (10 strands) and $M$. cathayana (9 strands) and the plant number of leaves for mulberry which use no treatment (control) for the $M$. alba (9 strands) and $M$. cathayana (8 strands). Compared to Kalimantan, the number of mulberry leaves in Bali is similar to $M$. alba (16 strands) and M. cathayana (13 strands) compared to the organic matter treatment for M. alba (11 strands) and M. cathayana (11 strands) as well as controls for $M$. alba (11 strands) and M. cathayana (10 strands) (Table 4).

The mulberry plant (Fig. 6) produces a favourable response to the growth of the number of leaves due to the administration of Rootone F. The Rootone F treatment has the best response on $M$. alba and M. cathayana compared with the organic growth regulators treatment, while the mulberry without Rootone F treatment and organic growth regulators (control) has the lowest value. Good leaf growth is related to the role of nitrogen that is absorbed by the roots for the plant growth process. Leaf growth has an important role in the formation of green leaves that are useful in the process of photosynthesis (Syros et al. 2004). Rootone given to plants in addition to accelerating the growth of roots, can affect the morphology of leaves, especially in the shape and variation of leaves (Drost et al. 2015).

The results showed that the concentration of Rootone F could increase the growth of $M$. alba and $M$. cathayana cuttings as indicated by the increasing number of leaves (Figure 6). Leaf growth will increase plant biomass (Benmahioul et al. 2012).

\section{Growth diameter of mulberry cuttings (cm)}

The results showed that Rootone $\mathrm{F}$ can increase the diameter of cuttings of $M$. alba and $M$. cathayana. Diameter of mulberry cuttings given Rootone $\mathrm{F}$ and organic substances have a noticeable difference. This difference was demonstrated by the treatment of Rootone $\mathrm{F}$ with a $15 \mathrm{ppm}$ concentration resulted in a better diameter for the cuttings while the organic and control substances yielded a lower diameter mulberry between $0.25-0.55 \mathrm{~cm}$ (Table 5).

Table 4. Average number of 3 months' mulberry leaves (strands)

\begin{tabular}{|c|c|c|c|c|c|c|c|c|c|c|}
\hline \multirow{2}{*}{ Species } & \multirow{2}{*}{ Time } & \multicolumn{3}{|c|}{ West Java } & \multicolumn{3}{|c|}{ East Kalimantan } & \multicolumn{3}{|c|}{ Bali } \\
\hline & & $\mathbf{R}$ & $\mathbf{O}$ & $\mathbf{C}$ & $\mathbf{R}$ & $\mathbf{O}$ & $\mathbf{C}$ & $\mathbf{R}$ & $\mathbf{O}$ & $\mathbf{C}$ \\
\hline M. alba & 7 DAP & $2 \mathrm{~b}$ & $1 \mathrm{ab}$ & 0 & $1 \mathrm{ab}$ & $1 \mathrm{ab}$ & 0 & $2 \mathrm{~b}$ & $1 \mathrm{ab}$ & 0 \\
\hline M. alba & 30 DAP & $7 \mathrm{c}$ & $5 \mathrm{bc}$ & $1 \mathrm{a}$ & $4 \mathrm{abc}$ & $2 \mathrm{ab}$ & $1 \mathrm{a}$ & $5 \mathrm{bc}$ & $2 a b$ & $1 \mathrm{a}$ \\
\hline M. alba & 60 DAP & $14 \mathrm{c}$ & $9 \mathrm{ab}$ & $5 \mathrm{ab}$ & $7 \mathrm{ab}$ & $6 \mathrm{ab}$ & $4 \mathrm{a}$ & $10 \mathrm{bc}$ & $7 \mathrm{ab}$ & $5 \mathrm{ab}$ \\
\hline M. alba & 90 DAP & $20 \mathrm{~d}$ & $17 \mathrm{~cd}$ & 12 abc & $15 \mathrm{abcd}$ & $10 \mathrm{ab}$ & $9 \mathrm{a}$ & $16 \mathrm{bcd}$ & $11 \mathrm{abc}$ & $11 \mathrm{abc}$ \\
\hline M. cathayana & 7 DAP & $3 \mathrm{c}$ & $1 \mathrm{ab}$ & 0 & $2 \mathrm{bc}$ & $1 \mathrm{ab}$ & 0 & $2 \mathrm{bc}$ & $1 \mathrm{ab}$ & 0 \\
\hline M. cathayana & 30 DAP & $6 \mathrm{c}$ & $4 \mathrm{bc}$ & $2 a b$ & $5 \mathrm{c}$ & $2 a b$ & $1 \mathrm{a}$ & $5 \mathrm{c}$ & $2 a b$ & $1 \mathrm{a}$ \\
\hline M. cathayana & 60 DAP & $12 \mathrm{~b}$ & $8 \mathrm{ab}$ & $5 \mathrm{a}$ & $7 \mathrm{a}$ & $5 \mathrm{a}$ & $4 \mathrm{a}$ & $9 \mathrm{ab}$ & $7 \mathrm{a}$ & $5 \mathrm{a}$ \\
\hline M. cathayana & 90 DAP & $18 \mathrm{c}$ & $16 \mathrm{bc}$ & $11 \mathrm{ab}$ & $13 \mathrm{abc}$ & $9 \mathrm{~b}$ & $8 \mathrm{a}$ & $13 \mathrm{abc}$ & $11 \mathrm{ab}$ & $10 \mathrm{ab}$ \\
\hline
\end{tabular}

Note: The numbers followed by the same letter are not significantly different in the 5\% Duncan Multiple Test. DAP: Day after planted; R: using Rootone F; O: using Organic and C: a control (using no added material)

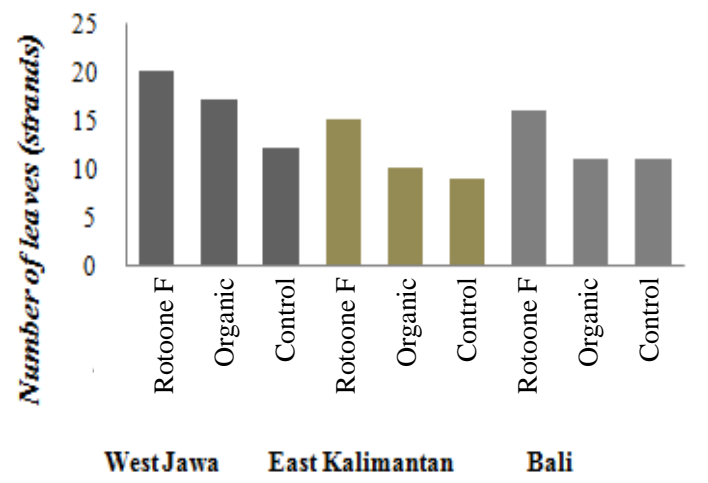

A

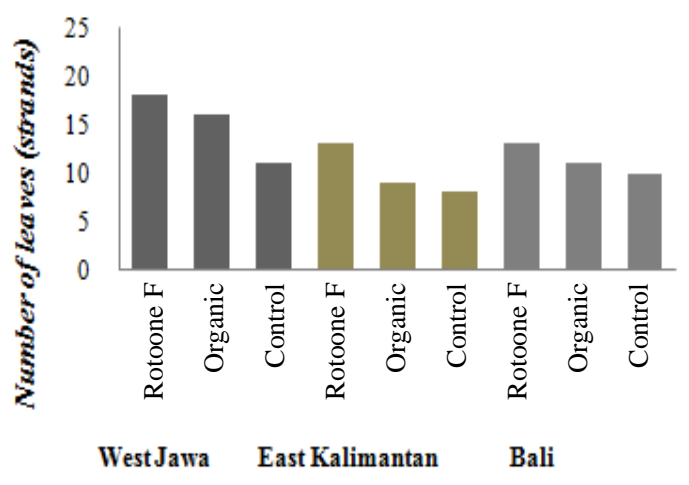

B

Figure 6. A. Number of Morus alba leaves (90 DAP), B. Number of Morus cathayana leaves (90 DAP) 
In general, Rootone $\mathrm{F}$ treatment may increase plant diameter in West Java for $M$. alba $(0.82 \mathrm{~cm})$ and $M$. cathayana $(0.75 \mathrm{~cm})$ compared with organic matter treatment for $M$. alba $(0.42 \mathrm{~cm})$ and $M$. cathayana $(0.43$ $\mathrm{cm})$ and control for $M$. alba $(0.30 \mathrm{~cm})$ and $M$. cathayana $(0.30 \mathrm{~cm})$. The growth of mulberry diameter in Kalimantan was lower than that of mulberry in West Java for M. alba $(0.49 \mathrm{~cm})$ and $M$. cathayana $(0.45 \mathrm{~cm})$. While the treatment of organic substances for $M$. alba $(0.41 \mathrm{~cm})$ and $M$. cathayana $(0.39 \mathrm{~cm})$ and control for the $M$. alba $(0.28 \mathrm{~cm})$ and $M$. cathayana $(0.25 \mathrm{~cm})$. When compared with in Kalimantan, the growth of mulberry diameter in Bali is almost the same, that is for the type of $M$. alba $(0.55 \mathrm{~cm})$ and $M$. cathayana $(0.48 \mathrm{~cm})$ compared with organic matter treatment for the type of $M$. alba $(0.41 \mathrm{~cm})$ and $M$. cathayana $(0.40 \mathrm{~cm})$ and control for $M$. alba $(0.29 \mathrm{~cm})$ and M. cathayana $(0.31 \mathrm{~cm})$.

Growth of high (Figure 7) shows that in general, the diameter of cuttings continues to increase. The highest average diameter of cuttings after 90 days mulberry planted was on Rootone F treatment followed by organic matter and control. From Figure 7, it is seen that giving Rootone F influences the growth $M$. alba and $M$. cathayana cuttings.
This is consistent with Salisbury and Ross (1992) which states that hormone treatment affects plant growth.

Salisbury and Ross (1992) suggest that ethylene content in plants causes cortical cells to synthesize cellulose, an enzyme that hydrolyzes cellulose and partially causes the breakdown of cell walls. In almost all high-level plants follow the same pattern of growth that forms sigmoid curves where growth is relatively slow in the early phases (seeds) and increases rapidly in the phases before flowering and back down after the flowering phase. This opinion is supported by Wattimena (1992) that success of growth regulator regimen is not always determined by the concentration of growth regulators and the timing of the application, but is determined by the plant growth phase. Auxin hormones help to accelerate growth, both root and stem growth, accelerate germination, help cell division, speed up the ripening of fruit, and reduce the number of seeds in the fruit. The auxin hormone is synergistic with cytokinin hormone and gibberellin hormone. The sunexposed plant grows slowly as the work of auxin is inhibited by the sun. So cause the tip of the plant tends to follow the direction of sunlight or called phototropism (Enders and Lucia 2015).

Table 5. Average diameter $(\mathrm{cm})$ of 3 months' mulberry plant

\begin{tabular}{|c|c|c|c|c|c|c|c|c|c|c|}
\hline \multirow{2}{*}{ Species } & \multirow{2}{*}{ Time } & \multicolumn{3}{|c|}{ West Java } & \multicolumn{3}{|c|}{ East Kalimantan } & \multicolumn{3}{|c|}{ Bali } \\
\hline & & $\mathbf{R}$ & $\mathbf{O}$ & C & $\mathbf{R}$ & $\mathbf{O}$ & C & $\mathbf{R}$ & $\mathbf{O}$ & $\mathrm{C}$ \\
\hline M. alba & 7 DAP & 0 & 0 & 0 & 0 & 0 & 0 & 0 & 0 & 0 \\
\hline M. alba & 30 DAP & $0.32 \mathrm{f}$ & $0.10 \mathrm{~cd}$ & 0 & $0.11 \mathrm{~d}$ & $0.04 \mathrm{~b}$ & 0 & $0.15 \mathrm{e}$ & $0.07 \mathrm{ab}$ & 0 \\
\hline M. alba & $60 \mathrm{DAP}$ & $0.64 \mathrm{c}$ & $0.31 \mathrm{~b}$ & $0.09 \mathrm{a}$ & $0.25 \mathrm{~b}$ & $0.10 \mathrm{a}$ & $0.09 \mathrm{a}$ & $0.28 \mathrm{~b}$ & $0.10 \mathrm{a}$ & $0.07 \mathrm{a}$ \\
\hline M. alba & 90 DAP & $0.82 \mathrm{~d}$ & $0.42 \mathrm{~b}$ & $0.30 \mathrm{a}$ & $0.49 \mathrm{bc}$ & $0.41 \mathrm{~b}$ & $0.28 \mathrm{a}$ & $0.55 \mathrm{c}$ & $0.41 \mathrm{~b}$ & $0.29 \mathrm{a}$ \\
\hline M. cathayana & 7 DAP & 0 & 0 & 0 & 0 & 0 & 0 & 0 & 0 & 0 \\
\hline M. cathayana & $30 \mathrm{DAP}$ & $0.25 \mathrm{~d}$ & $0.07 \mathrm{~b}$ & 0 & $0.12 \mathrm{c}$ & $0.06 \mathrm{~b}$ & 0 & $0.12 \mathrm{c}$ & $0.09 \mathrm{bc}$ & 0 \\
\hline M. cathayana & $60 \mathrm{DAP}$ & $0.61 \mathrm{c}$ & $0.29 \mathrm{~b}$ & $0.07 \mathrm{a}$ & $0.24 \mathrm{~b}$ & $0.10 \mathrm{a}$ & $0.07 \mathrm{a}$ & $0.26 \mathrm{~b}$ & $0.11 \mathrm{a}$ & $0.09 \mathrm{a}$ \\
\hline M. cathayana & $90 \mathrm{DAP}$ & $0.75 \mathrm{~d}$ & $0.43 \mathrm{c}$ & $0.30 \mathrm{ab}$ & $0.45 \mathrm{c}$ & $0.39 \mathrm{bc}$ & $0.25 \mathrm{a}$ & $0.48 \mathrm{c}$ & $0.40 \mathrm{bc}$ & $0.31 \mathrm{ab}$ \\
\hline
\end{tabular}

Note: The numbers followed by the same letter are not significantly different in the 5\% Duncan Multiple Test. DAP: Day after planted; R: using Rootone F; O: using Organic and C: a control (using no added material)

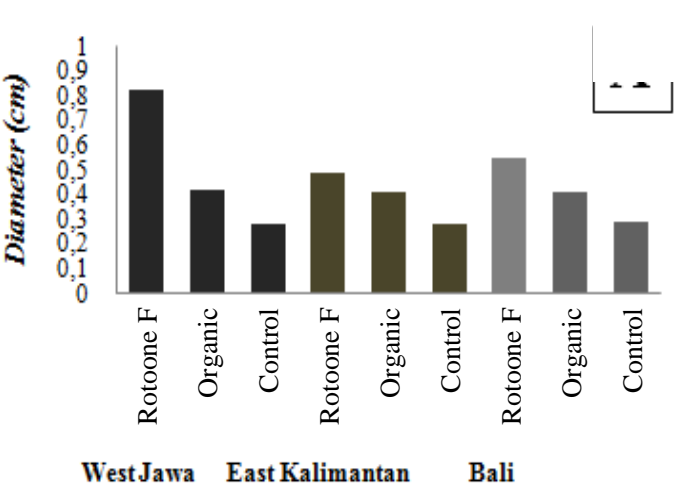

A

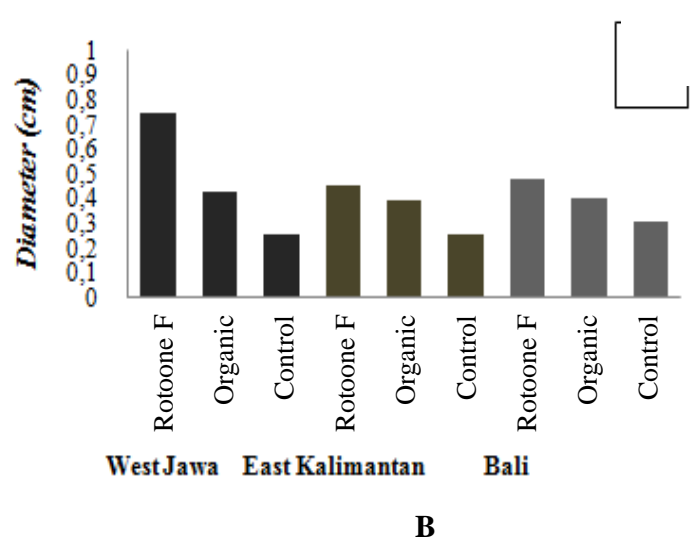

B

Figure 7.A. Morus alba diameter cutting (90 DAP), B.Morus cathayana diameter cutting (90 DAP) 


\section{Number of mulberry cuttings branches (buds)}

Mulberry that was given with Rootone $\mathrm{F}$ and organic substances did not differ significantly in the number of shoots. However, Rootone F with 15 ppm a concentration yielded good shoots, while organic and controlled substances produced lower shoots between $0.25-0.55 \mathrm{~cm}$ (Table 6). In general, Rootone F treatment may increase mulberry buds in West Java for M. alba (4 buds) and $M$. cathayana (3 buds) compared with the organic matter treatment for M. alba (3 buds) and M. cathayana (3 buds) as well as controls for the M. alba ( 2 buds) and $M$. cathayana (2 buds). The growth of the mulberry shoots in Kalimantan is lower than in West Java for M. alba (2 buds) and $M$. cathayana (2 buds). Similarly, the treatment of organic substances and control results are the same for the M. alba (2 buds) and M. cathayana ( 2 buds). Compared to Kalimantan, the growth of mulberry shoots in Bali has the same number, i.e. for M. alba (3 buds) and M. cathayana (2 buds) compared with the organic matter treatment and control for M. alba (2 buds) and M. cathayana (2 buds).

The Rootone F treatment of $15 \mathrm{ppm}$ is the appropriate treatment for the growth of the number of mulberry plants shoots (Table 6). Rootone can help increase the performance of auxins present in the plant thus helping to increase shoot growth. This is in accordance with the statement of Panjaitan, et al. (2014) that the performance of exogenous and endogenous hormones produced by roots can support the growth of plant buds. Salisbury and Ross (1992) suggest that exogenous and endogenous hormones can trigger the growth of buds otherwise it will prevent apical dominance so that bud growth is not inhibited.

A large number of shoots in the 90 days after planting (Figure 8) is due to a large amount of food reserves available at the mulberry cuttings. Food reserves as an energy source for the roots formation so that buds can grow optimally. Where the stem diameter size is directly proportional to the available food reserves amount. The absence of roots in the cuttings at the beginning of the cultivation forces the cuttings to utilize the reserve source from the stem. This is in accordance with Suwasono (1989) which states that in stem cuttings large diameter availability of food reserves more than a small diameter. This is supported by Hartman et al. (2002) which states that generally getting away from shoots, the diameter of the stem is getting bigger and the diameter difference directly affects the ability of cuttings to form roots and shoots because of differences in the type and variability of carbohydrates and stored materials.

Table 6. Average number of three-month-old mulberry plants buds

\begin{tabular}{|c|c|c|c|c|c|c|c|c|c|c|}
\hline \multirow{2}{*}{ Species } & \multirow{2}{*}{ Time } & \multicolumn{3}{|c|}{ West Java } & \multicolumn{3}{|c|}{ East Kalimantan } & \multicolumn{3}{|c|}{ Bali } \\
\hline & & $\mathbf{R}$ & $\mathbf{O}$ & C & $\mathbf{R}$ & $\mathbf{O}$ & $\mathbf{C}$ & $\mathbf{R}$ & $\mathbf{O}$ & $\mathrm{C}$ \\
\hline M. alba & 7 DAP & $1.0 \mathrm{a}$ & $1.0 \mathrm{a}$ & 0 & $1.0 \mathrm{a}$ & $1.0 \mathrm{a}$ & 0 & $1.0 \mathrm{a}$ & $1.0 \mathrm{a}$ & 0 \\
\hline M. alba & 30 DAP & $3.0 \mathrm{a}$ & $2.0 \mathrm{a}$ & $1.0 \mathrm{a}$ & $2.0 \mathrm{a}$ & $2.0 \mathrm{a}$ & $1.0 \mathrm{a}$ & $2.0 \mathrm{a}$ & $2.0 \mathrm{a}$ & $1.0 \mathrm{a}$ \\
\hline M. alba & 60 DAP & $3.0 \mathrm{a}$ & $3.0 \mathrm{a}$ & $2.0 \mathrm{a}$ & $2.0 \mathrm{a}$ & $2.0 \mathrm{a}$ & $2.0 \mathrm{a}$ & $2.0 \mathrm{a}$ & $2.0 \mathrm{a}$ & $2.0 \mathrm{a}$ \\
\hline M. alba & 90 DAP & $4.0 \mathrm{a}$ & $3.0 \mathrm{a}$ & $2.0 \mathrm{a}$ & $2.0 \mathrm{a}$ & $2.0 \mathrm{a}$ & $2.0 \mathrm{a}$ & $3.0 \mathrm{a}$ & $2.0 \mathrm{a}$ & $2.0 \mathrm{a}$ \\
\hline M. cathayana & 7 DAP & $1.0 \mathrm{a}$ & $1.0 \mathrm{a}$ & 0 & $1.0 \mathrm{a}$ & $1.0 \mathrm{a}$ & 0 & $1.0 \mathrm{a}$ & $1.0 \mathrm{a}$ & 0 \\
\hline M. cathayana & 30 DAP & $2.0 \mathrm{a}$ & $2.0 \mathrm{a}$ & $1.0 \mathrm{a}$ & $1.0 \mathrm{a}$ & $1.0 \mathrm{a}$ & $1.0 \mathrm{a}$ & $2.0 \mathrm{a}$ & $2.0 \mathrm{a}$ & $1.0 \mathrm{a}$ \\
\hline M. cathayana & 60 DAP & $3.0 \mathrm{a}$ & $2.0 \mathrm{a}$ & $2.0 \mathrm{a}$ & $2.0 \mathrm{a}$ & $2.0 \mathrm{a}$ & $2.0 \mathrm{a}$ & $2.0 \mathrm{a}$ & $2.0 \mathrm{a}$ & $2.0 \mathrm{a}$ \\
\hline M. cathayana & 90 DAP & $3.0 \mathrm{a}$ & $3.0 \mathrm{a}$ & $2.0 \mathrm{a}$ & $2.0 \mathrm{a}$ & $2.0 \mathrm{a}$ & $2.0 \mathrm{a}$ & $2.0 \mathrm{a}$ & $2.0 \mathrm{a}$ & $2.0 \mathrm{a}$ \\
\hline
\end{tabular}

Note: The numbers followed by the same letter are not significantly different in the 5\% Duncan Multiple Test. DAP: Day after planted; R: using Rootone F; O: using Organic and C: a control (using no added material)

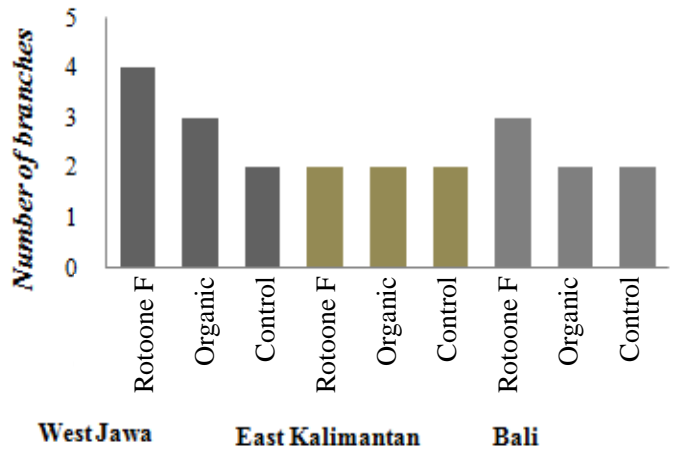

A

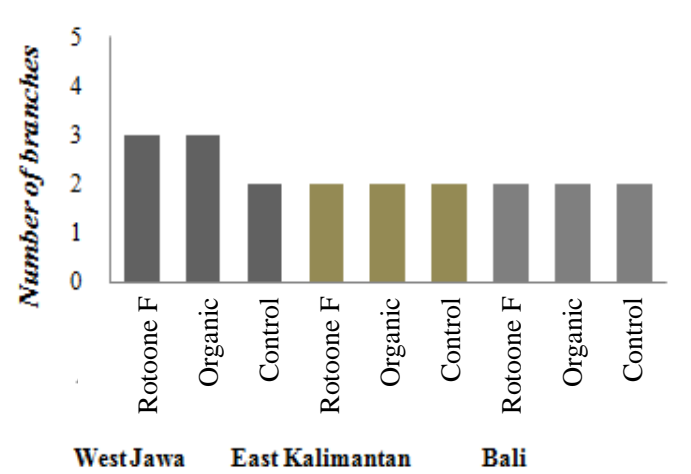

B

Figure 8. A. Number of Morus alba buds (90 DAP), B. Number of Morus cathayana buds (90 DAP) 


\section{Discussion}

The location biophysical condition has an effect on the mulberry plants cultivation, namely temperature, humidity, air quality, airflow and light. It is very important to adjust the microclimate for the mulberry plant adaptation and can produce many mulberry leaves. According to Agus (2013) the ideal conditions for mulberry cultivation are temperatures ranging from $15-30^{\circ} \mathrm{C}$ and humidity ranges between $65-90 \%$, also has fertile soil conditions with soil $\mathrm{pH}$ 6.5-7, with good soil aeration and soil drainage, its minimum soil solum is $50 \mathrm{~cm}$. Cianjur Regency West Java has a tropical climate with annual rainfall between 3000$3600 \mathrm{~mm}$. These climatic conditions make Cianjur has a fertile natural resources and a diversity potential natural resources. From the total area of $350148 \mathrm{Ha}$, its utilization covers $83034 \mathrm{Ha}(23,71 \%)$ is productive and conservation forest, $58101 \mathrm{Ha}(16.59 \%)$ is a wetland farming land, $97227 \mathrm{Ha}(27.76 \%)$ is dry farmland, $57735 \mathrm{Ha}(16,49 \%)$ is plantation land, $3500 \mathrm{Ha}(0,1 \%)$ is land and grazing, 1239 $\mathrm{Ha}(0,035 \%)$ is ponds, $25261 \mathrm{Ha}(7,2 \%)$ is a yard and $22483 \mathrm{Ha}(6.42 \%)$ in the form of use. Cianjur area of West Java is a near optimal condition for mulberry cultivation. Mulberry cultivation is suitable to be done at an altitude of 700-3000 $\mathrm{m}$ asl. There is enough sunlight. Rainfall between 2500-3000 $\mathrm{mm}$ per year in equally divided condition that is 8 months wet 4 months dry. Thus, the peak area of Cianjur, West Java with 900-2000 m above sea level altitude, including the ideal area for mulberry cultivation, maintenance of silkworms and good effect on the quality and quantity of cocoon produced.

The rainfall in Bali Island is generally included in the monsoonal rainfall pattern. This monsoonal rainfall pattern is characterized by a peak rainy season (unimodal) between December, January and February, and has a clear distinction between the rainy season and the dry season. The climate on the Bali Island is generally changing. Based on Scmidt-Ferguson climate type changing from relatively wet to dry, monthly and annual rainfall has decreasing tendency, average monthly air temperature generally increases, and there is shifting and changing number of wet and dry months. The impacts of climate change on forest ecosystems in Bali are unknown, but there are impacts as climate change implications on the forestry sector are forest fires and changes in planting time. In relation to the mulberry plant adaptation test, the Bali area has a good adaptation. However, compared with the West Java region is still less optimal, because of the relatively high temperature. Temperatures in East Kalimantan are between $27-35^{\circ} \mathrm{Cwith}$ annual rainfall average $1700-2000 \mathrm{~mm}$. The Rootone $\mathrm{F}$ use in mulberry plants in Bali and East Kalimantan initially gave a good effect, but high temperatures with the high sunlight caused it growth differently.

From the two mulberry species tested, it turns out $M$. $a l b a$ has the highest adaptation in Cianjur regency of West Java. It is proofed by the result of live percentage, plant height, and the number of leaves, diameter of cuttings, and the highest number of shoots. The M. alba at 90 DAP has a 95\% live percentage (Table 2), $80 \mathrm{~cm}$ plant height (Table 3), 20 leaves (Table 4), diameter $0.82 \mathrm{~cm}$ (Table 5) and 4 cuttings the highest (Table 6). The results are high in wet climates in Indonesia, as the percentage of live produced M. alba in Sulawesi is about 85\% (Nurhaedah et al. 2013). The highest percentage of life in M. alba is due to better adaptability to temperature and humidity compared to different species. This is indicated by the value of research results (about 90-95\%) which is not different between the two types of mulberry (Table 2).

The highest number of leaves on $M$. alba and $M$. cathayana in West Java caused the mulberry growth index to be higher than in Bali and Kalimantan (Table 4). The high number of leaves makes a wider surface of leaves to absorb solar radiation and increase the rate of photosynthesis and plant growth, so the plants absorb more nutrients from the soil, especially nitrogen. When the plant absorbs more nitrogen from soil, there would be more nutrition, so the plant can produce more leaf (Gardner et al. 1991). However, in Bali and Kalimantan, although the number of leaves is lower (Table 4), mulberry plants still can grow well. High temperature does not cause the leaves to wither or dry, but remain fresh and green. The leaves that grow not die but tend to be fresher, greener and grow normally. This suggests that the nutrients contained in the media are simple elements that are very easily absorbed by plant cuttings (Hansen et al. 1995). Nutrients absorption by mulberry cuttings, especially nitrogen absorption causes higher protein contained in mulberry plants, especially in its stems and leaves. The fibre content of mulberry is low, high levels of crude protein cause low levels of green fiber (Nitis et al. 1985). Forage protein content of more than 7\% is feasible as animal feed (Suprapto 2004).

The highest cut diameter average at 60 DAP was observed in Rootone F treatment in West Java. Rootone F affects the cuttings diameter growth of $M$. alba and $M$. cathayana. This is consistent with Salisbury and Ross (1992) which states that hormone treatment affects plant growth. When compared Bali and Kalimantan, although the number of leaves is lower (Table 5), mulberry plants can still grow well. The low growth of diameter is more due to less optimal factor of auxin hormone work. Other factors that affect the physiological conditions of the plant is the cuttings, good cuttings will produce the kind of mulberry plant which grows well. This is in accordance with Zong et al. (2008) that the physiological conditions of plants affecting the quality of cuttings are the age of the cuttings, the type of plants, the presence of young shoots and leaves, the supply of foodstuffs and growth regulators. The growth regulator substances used should be precise, if excessive concentration, it will cause poisoning in the plant. The composition of Rootone $\mathrm{F}$ compounds contains 1Naphthaleneacetic acid (NAA) with the formula $\mathrm{C}_{10} \mathrm{H}_{7} \mathrm{CH}_{2} \mathrm{CO}_{2} \mathrm{H}$. This colorless substance dissolves in an organic solvent. This compound (Dippy et al. 1954) has a carboxymethyl group $\left(\mathrm{CH}_{2} \mathrm{CO}_{2} \mathrm{H}\right)$ associated with naphthalene. NAA as a synthetic hormone in the form of auxin is a great ingredient for horticultural crops and is used for vegetative propagation of stem and leaf cutting. NAA hormones do not occur naturally like all auxin, this hormone is toxic to plants at high concentrations. In America, the NAA usage is watched under the Federal 
Insecticide Act, Fungicides, and Rodenticides. NAAcontaining plant products should be registered with the Environmental Protection Agency (EPA) as pesticide use (Benotti et al. 2003)

Rootone treatment increased shoots growth in mulberry species M. alba and M. cathayana in West Java. Rootone F helps increase the amount of auxin work in the plant so its increase shoots growth. This is the same with Panjaitan et al. (2014) statement, the performance of exogenous and endogenous hormones which produced by roots can support the growth of plant buds. Salisbury and Ross (1992) suggest that exogenous and endogenous hormones can trigger rupture of shoots and the growth of buds, otherwise it will prevent apical dominance so that bud growth is not inhibited. When compared in Bali and Kalimantan the appearance of shoots is slower (Table 6), however, the mulberry plant can still grow well. Slow shoot growth is more due to less optimal factor of hormone auxin work. Auxin hormones are more easily exposed to sunlight (Salisbury and Ross 1992). The unoptimal of organic substances, in general, cannot be determined exactly, the effect of organic substance to the growth of mulberry buds is not significantly different between growth with organic addition and control, because buds still can grow on the media without treatment. This is in accordance with the opinion of Haque et al. (1997) and Hansen et al. (1995). Auxin work according to Ludwig-Muller (2000) regulates the growth and development of plants through cell division, elongation and differentiation.IBA, auxin precursors which found as synthetic materials that induce root initiation in plants. Indole-3-butyric acid (1H-Indole3-butanoic acid, IBA) is a white substance with $\mathrm{C}_{12} \mathrm{H}_{13} \mathrm{NO}_{2}$ molecular formula. IBA is used to help plant roots (Goyal et al. 2012). IBA compounds are considered highly synthetic. In some plants, IBA has been shown to be synthesized in vivo using IAA and other compounds as precursors. Another composition of Rootone F is Thiuram. Thiuramdisulfide (Schubart, 2000) is an organosulfur compound of the formula (R2NCS2). Thiuramdisulfide obtained by oxidation of dithiocarbamates. This compound is used in the vulcanization of plants and pesticides.

Mulberry in various parts of Indonesia is to support silkworm business, but in East Asian countries such as China, India and Japan mulberry is used as a conservation plant. It is because this plant can adapt to dry and barren land. This study examined mulberry adaptation of dry land of Bali and Kalimantan. The results show mulberry can grow and adapt in Bali and Kalimantan, although the growth rate is not optimal as in wet climate area (West Java). In some countries, mulberry adapt to cold temperatures, hot temperatures, dry land and floods. Mulberry plants are able to withstand drought, effectively withstand wind, stabilize sand and soil conditions. Currently, mulberry plants are used as an ecological plant species for soil and water conservation especially for conservation in upland areas (Jian et al. 2013). Mulberry plants have high adaptability to the soil. The combination of mulberry plants with agricultural crops can increase the soil fertility value (Nithya et al. 2011). Soil with pH 5.3-8.4 is still growing normally (Rathore 2011). That is why the mulberry has a wide distribution and good growth. Mulberry plants have a strong survival. In arid or semiarid conditions until the desert region with the rainfall of less than 300-600 $\mathrm{mm}$ grows naturally. In the desert area of Xinjiang with $150 \mathrm{~mm}$ annual rainfall, it still grows well. In drought stress areas, the rate of photosynthesis, transpiration rates and water efficiency by mulberry leaves decreased. The indication that the mulberry has a strong resistance to drought is that it continues to grow chronically and no one dies (Huang et al. 2012).

The results study of the Jian et al. (2013) show that adult mulberry plants can survive from water puddles during their period of growth. It is very rare among other xerophytic plants. Mulberry plants that experience more than 1 meter deep still grow well. According to Stone (2009), mulberry plants were resistance to cold. The mulberry plant is resistant in cold conditions $\left(-30^{\circ} \mathrm{C}\right)$, and it also can survive in hot conditions $\left(40^{\circ} \mathrm{C}\right)$. For example, in America with a wide geographical range, mulberry plants can grow in various climates. The mulberry grows in areas with humid subtropical climates such as in Alabama $\left(27^{\circ} \mathrm{C}\right)$ with a summer. This occurs in semiarid climates in Colorado, with high temperatures and having a high potential of evapotranspiration rates. Mulberry can survive at cold temperatures in the Massachusetts region $\left(-5^{\circ} \mathrm{C}\right)$. Based on research in Bali and Kalimantan, mulberry plants in Bali which has a dry climate the plant live percentage is still relatively good for $M$. alba and M. cathayana (75$80 \%)$ compared to control (60-65\%). However, for other parameters of high cuttings, diameter, number of leaves and the number of shoots is relatively low for the Kalimantan region. The low growth in Kalimantan is strongly influenced by the high-temperature factor because its position which is right under the Equator line.

In conclusion, both types of mulberry (M. alba and $M$. cathayana) are able to be cultivated in various regions in Indonesia. The best mulberry of all parameters is $M$. alba which planted in West Java. Mulberry growth was low in the Kalimantan region, it is strongly influenced by hightemperature factors and geographical which are just below the Equator line. In general, $M$. alba species are more suitable to be planted in various regions in Indonesia with higher biomass productivity. However, the type of $M$. cathayana is capable in each location, while its productivity was lower than $M$. alba.

\section{ACKNOWLEDGEMENTS}

This search was funded by the Directorate General for Higher Education, Republic of Indonesia. Many thanks to the Ministry of Forestry, Forest Plant Breeding Center (BPTH) Bali-Nusa Tenggara at Denpasar, and Balai Pesutraan Alam at Pasir Sarongge, Cianjur who helped provide the research location.

\section{REFERENCES}

Agus N. 2013. Culture cultivation series of natural silk (Bombyx mori Lin). Silkworm Cultivation Guide. Bandung. [Indonesian] 
Benmahioul B, Dorion N, Kaid Harche M, Daguin F. 2012. Micropropagation and ex vitro rooting of Pistachio (Pistaciavera $\mathrm{L}$ ) Plant Cell Tiss Org Cult 108: 353-358.

Benotti MJ, Lee FP, Rieger RA, Iden CR, Heine CE, Brownawell BJ. 2003. HPLC/TOF-MS: an alternative to LC/MS/MS for sensitive and selective determination of polar organic contaminants in the aquatic environment. In: Imma F, Thurman EM (eds.). Liquid Chromatography/ Mass Spectrometry, MS/MS and Time of Flight MS. American Chemical Society, New York.

Dippy JFJ, Hughes SRC Laxton JW. 1954. Chemical constitution and the dissociation constants of monocarboxylic acids. Part XIV Monomethylcyclohexanecarboxylic acids. J Chem Soc 1954: 4102 4106.

Djamhari S. 2010. Breaking dormancy of ginger rhizome (Curcuma xanthorriza R.) using atonic solution and root stimulation with auxin application. J Sci Technol Indonesia 12: 66-70.

Drost DR, Swati P, Evandro N, Carolina RDBN, Christopher D, Oliver G and Matias K. 2015.Genetical genomics of Populus leaf shape variation. BMC Plant Biol 15: 166-167.

Enders TA, Lucia CS. 2015. Auxin activity: Past, present, and future. Amer J Bot 102 (2): 180-196.

Gardner FP, Pearce RB, Mitchell RL. 1991. Physiology of crop plants (Crop culture physiology, over language: Susilo and Subiyanto). UI Press. Jakarta.

Gomez KA, Gomez AA. 1995. Statistic Procedure for Agricultura Research. 2nd ed. UI Press, Jakarta

Goyal P, Sumita K, Kothari SL. 2012. Micropropagation of Pithecellobium dulce Roxb multipurpose leguminous tree and assessment of genetic fidelity of micropropagated plants using molecular markers. Physiol Mol Biol Plant 2: 18-19.

Gunawan LW. 1995. In vitro culture technique in horticulture.Penebar Swadaya, Jakarta. [Indonesian]

Gustini D. 2013. Effect of Rootone F and bayfolan on root formation and Salacca zalacca growth. Biospecies 6 (2): 8-13.

Hansen EE, Hubstenberger JF, Phillips GC. 1995. Regeneration of shoots from cell suspension-derived protoplasts of Allium cepa. Plant Cell Rep 15: 8-11.

Haque M.S, Wada T, Hattori K. 1997. High-frequency shoot regeneration and plantlet formation from root tip garlic. Plant Cell Tiss Org Cult 50: 83-89.

Hartman HT, Kester DE, Davies JrFT, Geneve RL. 2002. Plant propagation: Principles and Practices. The $7^{\text {th }}$ eds. Pearson, New Jersey.

Hidayati N. Saefudin. 2002. Growth and productivity of Orthosiphon aristatus on different microclimates and the liquid organic fertilizer treatment. Proceedings of the $2^{\text {nd }}$ national symposium on medicinal and aromatic plants.APINMAP. Bogor, 8-10 $0^{\text {th }}$ August 2001 [Indonesian]

Huang XH, Yin XH, Liu Y, Li JX, Xiong XZ, Chen Y. 2012. Effects of drought stress on growth of mulberry (Morus alba) trees in the hydro fluctuation belt of the three gorges reservoir area. J Chongqing Normal University. Natural Science 3: 151-155

Jian Q, He N, Wang Y, Xian Z. 2013. Ecological issues of mulberry and sustainable development. J Res Ecol 2: 330-339.

Kong WQ and Yang JH. 2017. The complete chloroplast genome sequence of Morus cathayana and Morus multicaulis, and comparative analysis within genus Morus L. PeerJ 5:e3037. DO 10.7717/peerj.3037.

Leopold AC. 1963. Auxin and plant growth. University of California Press. Berkeley, CA.

Ludwig-Muller J. 2000. Indole-3-butyric acid in plant growth and development. J Plant Growth Regul 32: 219-230

Mudiana D, Lugrayasa IN. 2001.The effect of the cutting material origin with the growing regulators treatment on the growth of Hydrangea macrophylla Thunb. Proceedings of the one-day seminar: Exploring the potential and improving the Prospect of Horticultural crops towards food security. Bogor Botanic Gardens, LIPI. Bogor, $5^{\text {th }}$ November 2000. [Indonesian]
Nithya D, Poornima RP, Murugan V, Gopikrishnan M, Radhakrishnan DBR, Balagurunathan. 2011. Influence of biofertilizer and irrigation system for the growth and yield of mulberry plants. Intl J Plant Anim Environ Sci 1: 93-99.

Nitis M, Lana K, Susila TGO, Uchida S.1985. Chemical composition of the grass, shrub and tree leaves in Bali. Project by products (Bali). Centre file: 3-P-77-0087 (IDRC). Supplementary report 1.Udayana University, Denpasar.

Nowak DJ. 2002. The effects of urban trees on air quality. USDA Forest Service. New York.

Nurhaedah M, Rizal HB, Achmad. 2013. Silkworm cultivation in Sudu village, Sub-district Alla, South Sulawesi. J For Res 4: 229-239.

Nurlaeni Y, Muhammad IS. 2015. Response of shoot cuttings Camelia japonica to the provision of organic growing regulator. Pros Sem Nas Masy Biodiv Indon 1 (5): 1211-1215. [Indonesian]

Orwa C, Mutua A, Kindt R, Jamnadass R, Simons A. 2009. Agroforestry Database: a Tree Reference and Selection Guide Version 4. www.worldagroforestry.org/af/treedb

Panjaitan LRH, Ginting J, Haryati. 2014. Growth response of various sizes of bougenvil cut trunk stems (Bougainvillea spectabilis Willd) against growing regrowth substances. Online J Agrotechnol 2 (4): 1384-1390.

Pasetriyani ET. 2014. The influence of various planting media and growtone growth regulator on the growth of stem cuttings of Jatropha curcas Linn. J Agrosci 7: 82-88.

Pulok MAI, Hossain MM, Haque MN, Poddar KK, Partho SG, Khan MSH. 2014. Effect of organic and inorganic growth regulators on germination and vigour of chickpea seed. Intl J Business Soc Sci Res 2 (2): 116-120.

Rathore MSY, Srinivasulu R, Kour GM, Darzi A, Dhar MAK. 2011. Integrated soil nutrient management in mulberry under temperate conditions. Eur J Biol Sci 3 (4): 105-111.

Rochiman K, Harjadi SS. 1973. Vegetative propagation.Department of Agronomy. Faculty of Agriculture, Bogor Agricultural University, Bogor.

Salisbury FB, Ross CW. 1992. Plant Physiology. 4th ed. Wadsworth Pub. Co., Belmont, CA.

Santoso B. 1999. Comparison of plant growth and leaf production multiple varieties of crops mulberry results in rainy and dry season. Forestry Research 5: 1-15.

Schubart R. 2000. Dithiocarbamic acid and derivatives.Ullmann's Encyclopedia of Industrial Chemistry. Wiley-VCH, Weinheim.

Siregar N, Djam'an F. 2017. The effect of plant material on the success of cutting of kranji (Pongamia pinnata). Pros Sem Nas Masy Biodiv Indon 1 (3): 23-27. [Indonesian]

Stone KR. 2009. Morus alba. Fire effects information system. U.S Department of Agriculture, Forest Service. Rocky Mountain Research Station. Missoula, Montana.

Suprapto, Suratmini NP, Adijaya. 2004. "Performance of three superior varieties of maize on dry land village of Patas Gerokgak, Buleleng. Proceedings of national seminar on revitalization of creative technology in supporting agribusiness and regional autonomy. Denpasar, $7^{\text {th }}$ October 2003. [Indonesian]

Suwasono H. 1989. Plant Hormone. Rajawali Press. Jakarta. [Indonesian]

Syros T, Yupsanis T, Zafiriadis H, Economou A. 2004. Activity and isoforms of peroxidases, lignin and anatomy, during adventitious rooting in cuttings of Ebenus cretica L. Plant Physiol 161: 69-77.

Utami NW, Hartutiningsih, Siregar M, R.S Purwantoro RS. 2000. Propagation of Podocarpus spp. with provision of growth regulators: IBA, NAA, IAA and 2,4D. Daily seminar proceeding: Exploring potential and improving the prospect of horticultural crops towards food security. LIPI. Bogor, $5^{\text {th }}$ November 5, 2000. [Indonesian]

Wattimena GA, Gunawan LW, Matjik NA, Syamsudin E, Armini NMA, Ernawati A. 1992. Plant Biotechnology.Tissue Culture Laboratory, Bogor Agriculture University, Bogor.

Wudianto R. 1999. The making of cuttings, grafts and fraftings. Penebar Swadaya Publisher. Jakarta. [indonesian]

Zong MC, Yi Li, Zhen Z. 2008. Plant growth regulators used in propagation. CRC Press. Boca Raton, FL. 